\title{
THE AMERICAN MILITARY PRESENCE IN THE ARAB GULF REGION
}

\author{
ABDUL-JABBAR ISMAEL IBRAHIM \\ M. A Instructor, College of Political Science, University of Baghdad \\ Al - JADRIYA Complex, Baghdad, Iraq \\ DOI: $10.37648 /$ ijrssh.v10i02.001 \\ Received:15 ${ }^{\text {th }}$ November, 2019; Accepted:30 ${ }^{\text {th }}$ December, 2019; Published: $24^{\text {th }}$ January, 2020
}

\begin{abstract}
The importance of the Arab region, and the Gulf region in particular with regard to Washington, has increased, especially after the decision to ban oil exports, as this importance has increased with the Iranian revolution, and Iran has adopted policies to export the revolution specifically targeting the Gulf region, and its influence has increased there, which means harming Washington's interests, especially Moscow did not oppose the revolution.

Using the "Masirah" island of the Sultanate, which contributes to controlling the entire Gulf region. The October 1973 war and the oil embargo that accompanied it contributed to crystallizing a new pattern of American projects towards the Gulf, which are projects of direct military intervention if the Iranian revolution and Soviet intervention in Afghanistan were the most important changes that affected the course of US policy in the region, but that The outbreak of the IraqIran war.

In light of these changes, the American strategy in the Gulf gained new features, and the policies of the American forces were taken, obtaining rules and facilities, and developing the capabilities of direct intervention.

This led to the United States seeking to obtain maritime facilities and bases in the Arab Gulf countries, especially during the era of the current US President Donald Trump, and the reason to confront the Iranian expansionist project in the region, which ultimately threatens the national security of the Gulf states .

Keywords : American military . presence. Arab Gulf region
\end{abstract}

\section{INTRODUCTION}

The role of American security policy and how to understand it are central to the issue of foreign military presence in the Gulf region, and the roots of the global security system of the United States extend to the period after the Second World War, especially with Britain's decay as a guarantor of a harmonious security system, and the emergence of the Soviet Union, and at a time $\mathrm{He}$ pursued China as a perceived threat to a Western understanding of world order.
The United States forced the reliance on the rights to establish bases on the lands of the allies, or to rent facilities from the host countries, as many were preparing the global security system for the United States in the eighties of the twentieth century, overstretched, due to the huge economic costs and political opposition abroad, and at home, and carried The end of the Cold War, promising to reduce pressure on America's needs. But the coming years have created more requirements for the deployment of American forces overseas (the invasion of Kuwait, chaos in the 
Balkans, and the US-led invasion against both Afghanistan and Iraq), that the argument of a foreign military presence by a foreign power depends, of course, on its perceptions of security threats in its vicinity, and its perception Severity or likelihood of these threats.

The Gulf region was the most appetite for the United States, which started to escalate the ladder of greatness very quickly after the Second World War, because of what the Gulf countries store of oil and Oga, and because of its distinctive location in Islamic Central Asia (Iran, Afghanistan, Pakistan, Iraq, Yemen, and Saudi Arabia) ) Of riches. The United States announced after the invasion of the Soviet Union in Afghanistan (December of the year 1979) that "the Arabian Gulf is a region that includes vital interests for its security" and that it will not allow any external interference in it.

Rapid intervention "in the region at the first Gulf War between Iraq and Iran in 1980.

The American military objectives in the Gulf appear clear, namely: "American goals and interests, and the importance of military bases in ensuring these interests, and in supporting American political goals

The United States of America succeeded in establishing military and economic relations with the Sultanate of Oman, as it signed with it (America) on 4/6/1980, an agreement that allows the United States to access the Omani military bases and use them after consulting the other side in exchange for an American commitment to defend Oman, where the states The United States is building strategic bases over some of the mountains overlooking the Strait of Hormuz under the slogan of establishing construction projects supervised by this committee.

Gulf sources indicated that the American forces have set up a series of bases in Musandam, the most prominent of which is a "large base in Habailin for communications and sophisticated espionage that reveals the entire region to Iraq, as well as radar stations in" Lima ", and safety islands to monitor the movement of ships, and also developed a base" Thumrait "located Near the border with Yemen, and the base of "Masirah", and established a developer in Al-
Ghanam Island, and obtained the right to use the Seeb and the Matruh Port. Therefore, the Pentagon approved more than half of the amounts allocated to build bases and facilities in a number of countries in the region for Oman, where the total costs reached (270) 3) million dollars.

In order to secure the arrival of oil supplies at prices as securing the stability of this region has become a vital interest for the United States, so it has established many military and air bases in it, in addition to its military presence in Afghanistan, the United States has bases of establishing them after the end of the Cold War in eastern Europe, such as Poland, Romania and Bulgaria , As it has several advantages, the most important of which is "its proximity to the sites of direct security threat in the Middle East region".

And once the American war on terrorism in Afghanistan ended and the American military deployment in the region was completed by the new bases in the Asian countries, the American focus shifted to Iraq

After Iraq's invasion of Kuwait, the Arab Gulf states 'preparations were strengthened by granting the United States access to its military bases and facilities, but before the invasion, these countries would have preferred that the American forces remain on the horizon, especially since this applies to Saudi Arabia, where you find the idea of a Western forces on holy land, sharp Islamic opposition, and the American forces have learned that their presence is not evident and tangible, until they have transferred their facilities to all the depths of the Saudi desert, and despite that, the Islamic militants have counted Saudi Arabia's dependence on American forces with His house is a reaction to Islam, but Iraq's invasion of Kuwait showed the leaders of the Gulf states how weak their small oilrich countries were. The Kingdom of Saudi Arabia has given the US Air Force planes access to its air bases, as well as all six Gulf countries, starting with the defense cooperation agreements for Bahrain with the United States, and establishing a headquarters for the US Fifth Fleet in 1995, as well as the State of Qatar, which signed a defense agreement in 1992, Then the State of Qatar built a giant air base in Al-Udaid, and in 2002, 
the US Central Command established headquarters. As for the UAE, it signed a defense agreement in 1994 with the United States. Finally, the Sultanate of Oman allows the arrival of strategic bombers for US Air Force planes at the Masirah and Sib air bases and Thumrait.

.The countries of the Cooperation Council for the Arab States of the Gulf fully fit the future view of the Pentagon on foreign presence, as it provides basic requirements for front bases, facilities for leaderships, background installations, rights to pre-position forces and equipment, and transit rights, and its role is that it is a support platform, and includes the foreign military presence.( 1)

In its case, it contains the three components of the Ministry of Defense strategy: major bases, forward operating sites, and cooperative security placements

,Kuwait provided a wide range of assistance to the American forces, and allowed for the extensive use of Kuwaiti lands and buildings, and this appears to be due to the fear of Iraq, followed by a sense of shared responsibility regarding rebuilding post-Saddam Iraq.

As for Bahrain, it includes the leadership of the American Fifth Fleet, while the UAE prefers (which allows the stopping of ports, the use of the Al Dhafra air base), and the Sultanate of Oman (which allows the advance positioning of troops and equipment, and the use of air bases).

The American military presence in Qatar has grown as part of a deliberate policy to enhance US-Qatari relations

Because of the negative consequences of the military presence, and in light of the popular rejection and an anti-Western climate with the spread of Islamic extremism in the region, the closest possibility will be to prepare for a military presence in a location close to the region through maritime or ground bases, and to provide the region with modern weapons and encourage them to cooperate together and joint training between them

.The first axis: American bases in the Gulf states

First: Bahrain( 2)
American policy concerned with establishing military bases, obtaining marine facilities in the Gulf region as a tool to secure their interests, and achieving their goals. The American military presence began at the "Juffair" base in the year 1949, by obtaining facilities for their fleets in that base. The United States entered into direct negotiations with Bahrain to remain in Juffair, on the pretext of "filling the void" left by the British withdrawal from the Gulf, and then acquired the US military presence in the Gulf another dimension with the beginning of the year 1975, when it concluded an agreement between the Sultanate of Oman and the United States, according to which the use of an island The "Masirah" of the Sultanate, which contributes to controlling the entire Gulf region. The October war and the oil embargo contributed to crystallizing a new pattern of American projects towards the Gulf, which are direct military intervention projects, and if the Iranian revolution and the Soviet intervention in Afghanistan constituted the most important changes that affected the course of US policy in the region, but the outbreak of the Iraq war - Iranian. In light of these changes, the American strategy in the Gulf has acquired new features in obtaining rules and facilities, and developing the capabilities of direct intervention

Bahrain played a distinguished role in assisting American forces, and in the second Gulf war against Iraq in 1991, Bahrain provided extensive facilities to the US-British coalition forces. This military relationship with the United States culminated in a "joint cooperation" agreement in 1991, and this agreement allowed the United States of America to establish in Bahrain the headquarters of the "US Central Commandment Headquarters" for its forces, and since 1993 it became the Central Command of the US Navy (US Central commandment) in Bahrain, as Bahrain became the headquarters of the American "Fifth Fleet", while parts of the Fifth Fleet were anchored at the Port of Solomon, and America had warehouses for equipment and supplies in it.

First: Sheikh Issa Air Force Base: Sheikh Issa Air Force Base is located in southern Bahrain, and the base hosts the BAAF Combat Wing, and two divisions. The US government has provided assistance to build other sites in this base to accommodate F-16s, and it has also been 
able to accommodate the combat division. Second, they kept building fortified shelters and the headquarters of American submarines in the air port of al-Qaeda. When the Iraqi forces entered Kuwait in August 1990, they transported $(12,000)$ fighters and played an important role, from which various fighters were used to strike Iraq.

Second: Muharraq Air Base: The Muharraq Air Base is located near (Manama), the capital of Bahrain, and it represents one of the American military units in the Persian Gulf, and the American P-3 naval teams and patrols operate at the Al-Qaeda airport. In addition to (UC-12M) it provides Muharraq base airport is transportation and support services for travelers in the (Central Command) area of the US Central Command, in which a number of tanks (101) Airborne Division are stationed, and it also accommodates (80) aircraft

Second: Kuwait

Relations between Kuwait and the United States of America began to take a new path, due to the Kuwaiti fear of neighboring Iran, especially after the bombing of a Kuwaiti oil tanker by Iran in 1987, then Kuwait's approach to Washington increased when Iraq invaded Kuwait, which necessitated the establishment of an alliance of countries Arab and Western led by America itself against Iraq, bypassing the countries of the Damascus Declaration, which participated in military units of their armies in the American war to liberate Kuwait. The price of liberating Kuwait from Iraq was financially high, as well as securing it from any Iranian aggression. Kuwait paid the United States during this war $(16,100)$ billion dollars.

The American forces have been stationed in most of the Kuwaiti military sites, and are cooperating effectively with the Kuwaiti army

The bases where the forces are stationed are

First: Ahmed Al-Jaber Air Force Base

This base is located in Kuwait, at a distance of (75) miles from the Iraqi border. This base was established as part of the military operations of the American Air Force and other allied forces at that time in the Arab
Gulf region. One of the duties of this base is to support the joint mission force - Southwest Asia It was monitoring the no-fly zone in southern Iraq

Second: Ali Al-Salem Air Force Base.

This base is located in the west of Kuwait, (39) miles from the Iraqi border. This base was designed to be part of the operations of the American Air Force and its allies in the Arab Gulf region, and it is an important, small and resistance base on flat ground, and it has the responsibilities of monitoring, reconnaissance, control, protection and administration. Air operations and directing anti-ballistic missile defense missiles through the (Patriot) system charged with protecting American forces from any air threat in accordance with specific programs

Also, there are the camp of Doha, Failaka Island, Kuwait Airport, Mina Al-Ahmadi and Camp Arifjan, where forces of various weapons (air, land, marine, and command) are stationed. There are (52) combat aircraft in Kuwait, in Kuwait (75) Apache helicopters, and a number of "Patriot" anti-missile units, and there are about ten thousand American soldiers, not to mention the numbers of teams and land, and air units, which were taken from Kuwait Base for launching the last war on $\operatorname{Iraq}(3)$.

Among these camps:

The camps are:

First: Al-Arefjan Camp.

Al-Arefjan camp is located $(60 \mathrm{~km})$ south of Kuwait City, and it was built at the expense of the Kuwaiti government at a cost of (200) million dollars, as the base provides permanent support facilities for the American forces in Kuwait, and this base has replaced the old facilities that were used in the Gulf War The second was in 1991, after it was equipped with all American military equipment (4).

Second: theKapal camp.

Camp (Cabal) is located in the northern part of Kuwait, less than (50) miles from the Iraqi border, and the area of this base is estimated at $(1,600)$ square miles. As for 
the training area conducted by the US and allied forces, it reaches $(6,900)$ square miles. And this camp was established after the second Gulf War in 1991, with the aim of protecting the coalition soldiers, and making them able to carry out special missions in the future. This base has been provided with advanced equipment as well as tanks, and a number of military units prepared for rapid and direct action. It is worth noting that the operation (Desert Fox) that was carried out against Iraq during the month of February 1998 was carried out through this base, and that it strengthened the direct American presence in The Gulf region is "the state of instability and chaos as a result of successive events, starting with the Iranian revolution in 1979 and passing through the Iran-Iraq war in the 1980s and then the Iraqi invasion of Kuwait in the 1990's (5)

Third: The State of Qatar

Qatar was the third rank for the six Gulf countries that signed a defense agreement with the United States of America, as until the Tanker War * in the year (19871988), there was no development in the security arrangements between the two countries, but this development started during the second Gulf War, where Qatar allowed US Air Force units to use its territory during this war, and in 1991, the US Armed Forces established an office in Doha. In June of the year 1992, bilateral negotiations began between Qatar and the United States to reach a "defense cooperation agreement" between the two countries, and since the signing of this agreement between Qatar and the United States, the American Air Force has been allowed to use the Qatari airspace, and the American Navy has also been able to benefit from distinct maritime facilities. In March 1995, Qatar agreed to store "heavy equipment for an American automatic brigade" on its soil, and began building warehouses for this equipment in Doha, and the Qatari Air Force began "joint exercises" with the US Air Force, which gained several locations, and from the major bases The American in Qatar, mention the following ( 6):

First: Al-Sulayyila base. Its area is (262) acres, and cost more than (100) million dollars. It was completed in the year 2000, and it contains more than (20) warehouses suitable for all climates, and (900) M1 tanks, combat vehicles, and others. Of the armed mechanisms, the base can store enough equipment and weapons for an entire army brigade, as well as a housing complex for soldiers.

Second: Al-Adeed Air Base. This base is located (45) $\mathrm{km}$ south of the Qatari capital (Doha), and (483) km southeast of Iraq, and the strategic importance of this base lies in that it was built on a flat plain without rugged terrain or other obstacles. The vision is like mountains and plateaus, which provides a wide and convenient field for vision and wireless communications including radar devices capable of monitoring movements without barriers or obstacles (7)

. It is worth noting that this base had a prominent role during the American attack on Afghanistan to pursue (Osama bin Laden) the leader of the Al Qaeda network and its followers In terms of launching raids, and thrown $\mathrm{M}$ on exploratory missions, and following the restrictions imposed by Saudi Arabia on the movement of American forces on its soil, the US Department of Defense (the Pentagon) carried out the transfer of equipment from Saudi Arabia, especially from Prince Sultan Air Base to the Qatari base of Al-Ahdid, knowing that this base is of a dual nature. For the purposes of the main deployment, and for logistical support purposes, the United States spent billions of dollars on establishing an advanced air command center at Prince Sultan Air Force Base after Operation Desert Shield in the year 1991, and it also spent another 1.5 billion dollars on establishing an air base in the State of Qatar The analyst comments on the affairs of A. Security at the Defense Information Center in Washington (Marcus Corbyn) in an interview with the British Guardian newspaper on this matter, saying, "The spread of the American military bases is witnessing a state of astonishing development, in every sense of the word, and it is a disturbing development from the viewpoint of the rest of the world. One of the most prominent results of the Iraq war is "the United States redoubling its efforts to diversify its current and future sources of strength ( 8)

Fourth: The Sultanate of Oman:

Oman's strategic location at the Strait of Hormuz is an important factor in the aspiration of countries with 
interests in and through this region to acquire a position in this Gulf country. Among the most important of these countries, there is no doubt: the United States of America, then Britain and France, where security cooperation between the United States began The United States and the Sultanate of Oman since the Dhofar Revolution in the year 1980, when the United States provided (Oman, Britain, and Iran) economic "unofficial" military aid, as well as providing them with support during their confrontation with the People's Democratic Republic of Yemen, and during its handling of the threats that resulted from the Iraqi war. - Iranian, and that $\mathrm{m}$ It can be granted (i.e. America) military and maritime facilities, and this was done according to an agreement signed in 1980, followed by the signing of an official declaration from Amman that it "gave the United States facilities to use its ports and airports" on the guaranteed borders of friendly countries, and Oman did not soon In the same year (1980), it allowed the establishment of a "US CenteralGommandment" on its soil, for the exercises that the forces began conducting in Amman, then granted the US Navy naval facilities, and it also provided both the United States and the United Kingdom with the data that are available to them. Oil tankers crossing the Strait of Hormuz, and in July AD 1981, the Sultanate of Oman was held with the United States military agreement under which allowed US forces to build warehouses and stores Mlajyaue air in Seeb and Masirah and fertility and Thumrait, and ports in Muscat and Salalah. Oman allowed the United States and Britain to use its lands as a gathering base for their forces and planes during the tanker war, and the first and second Gulf wars. It also allowed American aircraft to use the bases and the Omani field when American aircraft attacked the terraces of Iranian oil in the Gulf. Oman was the first country in the Gulf to cooperate militarily with the United States of America, and it also provided important support, for a long time, to the American naval and naval weaponry in the region, and the military-security cooperation between the two countries is continuing and developing( 9)

First: Masirah rule

This base is located on the island of (Masirah) along the eastern coast of the Sultanate of Oman, and it is considered one of the most important islands of the Arabian Gulf by virtue of being overlooking the Arabian Sea, and its area is estimated at (65) km long and (15) $\mathrm{km}$ wide and the strategic value of the (Masirah) base is that it constitutes The US Air Force's openness is strategically based, as it affects in terms of control and control in both the Strait of Bab al-Mandab and the Strait of Hormuz, which gave the American forces an opportunity to supervise the Arabian Gulf, the Arabian Sea, and the Indian Ocean. The path of its presence on this sensitive island (10) .

Second: Tooth gear base. It is located in the Al-Musnah area of Oman, $120 \mathrm{~km}$ west of the capital, Amman. The Sultanate of Oman, along with the American air force, contributed to building this base, and the Sultanate of Oman declared that this "toothed" land is for the use of American aviation

\section{(11) Fifth: The United Arab Emirates.}

Military cooperation in the field of security between the United Arab Emirates and the United States of America began during the "Tanker War" (1987-1988), in the Gulf in 1991, when the Emirates provided the Americans with facilities in its ports, and the US Navy conducted joint exercises with the Emirati forces, and in 1992 The UAE held negotiations with the United States to establish "security arrangements" between the two countries, as the UAE provided military air and naval facilities, and then the two countries signed a defense cooperation agreement on July 23 in 1994, and the UAE was the fifth country to sign such an agreement after Kuwait Bahrain, Qatar and Oman The United States stores limited quantities of equipment and devices in the Emirates, in Jebel Ali and Fujairah it stores equipment for its navy, and Jebel Ali is one of the most used regions in the world by the American Navy, and Fujairah on the Gulf of Oman is one of the ports that allow the passage of American logistical support to reach To the Gulf without going through the Strait of Hormuz, thanks to the "highway" that connects the ports of Fujairah to the southern Gulf, and in a joint statement issued by the former US Vice President Al Gore and the Crown Prince of Abu Dhabi during his visit to Washington from 12-14 / 5/1998, in which he stated that relations The bilateralism between the two 
countries has expanded to include "cooperation." On construction and joint in the commercial, educational and security fields, and that these close ties have become an effective factor in protecting security and stability in the Arab Gulf region, then Sheikh Khalifa bin Zayed announced that his country will obtain "(80) F-16 fighter aircraft", considering this an important step Towards supporting the defense capabilities of the Emirates, which will allow the UAE to achieve a reliable defense system, and build a traditional capacity based on quality and quality, which will help to achieve stability in the overall strategic balance in the region

The United Arab Emirates has become important in relation to the strategy of the "American Central Command" in the region, especially since the Emirates that connect to Bahrain are: the Arab Gulf and the Gulf of Oman, and overlooks one of the most important straits in the world, which is the (Strait of Hormuz) that connects the Gulf of Oman And the Arabian Gulf, separated by two large Islamic blocs: Iran and the Arabian Peninsula, which is rich in oil, which has become "the key to support for US activities in the Gulf region( 12)".

The American forces have facilities in a number of Emirati sites and bases, such as Al Dhafir Air Base in Abu Dhabi, Fujairah International Airport, Rashid Port, Jebel Ali, Fujairah and Zayed Port, and there are no military bases for the Americans in the Emirates, despite the presence of (500) American soldiers.

As for the main proliferation bases in the United Arab Emirates (13).

Al Dhafra Air Force Base is located in the United Arab Emirates, and the Air Feeding Group (763) and the Temporary (4413) Air-Feeding Group Associated with the Air-Feeding Group are located in Southwest Asia, and are equipped with (KC-10) air-feeding aircraft, and aircraft supports The American War, and Al Dhafra base is the largest base in (Abu Dhabi), and it is worth noting that the United Arab Emirates provided great support to the United States of America and its allied forces, as it allowed them to deploy planes, use its airspace, and give them all facilities from their military bases, even a process Provide equipment and WOQOD as part of surveillance operations in southern Iraq, and that this base is one of the four bases in southwest Asia that are Prince Sultan Air Force Base, and Ali Al Salem and Ahmed Al Jaber air bases in Kuwait, and Al Dhafra Air Force Base in the United Arab Emirates where combat units (RMS) are deployed ) And that works throughout the year, and it must be pointed out the role that this base played in the occupation of Iraq in April of 2003 by allowing American forces to use the UAE bases, especially the Al Dhafra Air Force base.

Sixth: The Kingdom of Saudi Arabia (14).

Although there is no formal military treaty between the United States of America and Saudi Arabia, the ties were close between the two countries, the first of which was when the United States rented the Dhahran air base and its port on the Persian Gulf in 1943, and continued until 1962, and the cooperation of the two countries increased In the year 1983, in military preparations against Iran (during the Iran-Iraq war), it conducted military exercises and exercises with the American army in establishing my name as (Fahd Line) which is the defensive line that established an air-protected area along the Saudi coast, which helped Saudi Arabia this Collaboration, to be secure A well-rounded airspace, especially in the tanker war of the year (1987-1988), and in the Gulf War (second), Saudi Arabia cooperated fully with the coalition forces in the (Desert Storm) operation led by the United States to liberate Kuwait, and in light of the agreement signed between the two countries in the year 1965, which It includes conditions related to the legitimacy of the presence of US forces in Saudi Arabia, and also included the establishment of three large camps: the first / in "Khamis Muscat" on the Yemeni border, and the other / in Tabuk in southern Jordan, and the third / King Khalid Military City in Al Bateen, and since the Gulf War Saudi Arabia has expanded Its military and security cooperation with the United States, and over a year M that Saudi Arabia did not formally agree to the stationing of US military units on its territory, but its forces conducted several exercises with US ground forces, and in 1992, Saudi Arabia was held with the US Army military agreement to train the Saudi army (15)

The American forces have several facilities in Dammam, Hofuf, Khobar, Tabuk and Yanbu, the King 
Fahd Naval Base in Jeddah, as well as the King Khalid Air Force Base in Abha, the Riyadh and Taif military bases, and the Prince Sultan Air Force Base south of Riyadh, which are the most occupied by these forces and at the King Abd base Dear dahran

We will mention some of the US military bases in Saudi Arabia.

First: Jeddah Air Force Base: Jeddah Air Force Base is located in the western side of Saudi Arabia on the Red Sea coast, and it is equipped with three missile batteries. The Jeddah air base during the second Gulf war in 1991 played a critical role in three main areas, namely, providing the rapid deployment of military allied forces, as well as providing support and assistance to these forces from this base, as well as the use of this base in large and complex combat operations, where It is located at the Jeddah Air Force base, the US Military Training Mission of the US Central Command for training purposes, and this base is of a dual nature, it is for the purposes of major deployment, and for training purposes (16).

Second: The Housing Village:

This village is located in Saudi Arabia, at a distance of (20) $\mathrm{km}$ south of Riyadh, and in this base there is a large residential complex for the individuals of the Air Force, and there are members of the Central Command of the US Army forces for maneuvers, and to control the work of the Patriot missile system in Saudi Arabia.

Third: Horoscope news:

Al-Khobar Towers are located in Saudi Arabia, which is a "residential complex that was built by $\mathrm{Al}-\mathrm{Sa}$ 'wiya in the year 1979, near the city of Dhahran in the eastern region of Saudi Arabia, where these towers consist of distributed residential apartments, and when the Central Command of the US Army Forces in Saudi Arabia was established The command personnel in these towers, and they were given a dual role, by leading the air defense mission inside Saudi Arabia on the one hand, and multiple logistical responsibilities on the other (17).
Fourth: Prince Sultan Air Force Base:

This base is located in Saudi Arabia in a desert part known as (Al-Kharj), so it is also called as (Kharj Air Force Base), and this base hosts (4,500) American soldiers, and a large number of aircraft, and this base is very large, with an estimated size of (80) miles Square, and there are large facilities for keeping the aircraft, and Prince Sultan Air Base is receiving special attention by the American military command, so I worked to provide its forces present in this base with hundreds of computers, and an intelligence center, and there are also elements of this base from the AFCA, And is responsible for engineering and design of the network infrastructure For systems that support command, control over the base, and includes network infrastructure work three network services, namely:

\section{Al-Qaeda Internet Network Check (NIPRNET.}

\section{OSIPRNET.}

COIN information processing network( 18)

The second axis: the Carter Doctrine; 1980 to ensure oil and natural gas found in the Middle East and its impact on the US military presence in the Persian Gulf

The geo-political, military, and economic goals of the United States varied around the reasons for the existence of its military bases, deployed in the Gulf Cooperation Council countries.

But what is striking about this diversity is that it was variable with the change of time and events. When the idea of military bases began to stagger American imagination, the American administration's justification was to create a military force capable of confronting the power of the Soviet Union, and the Soviet Union was not the only curtain for the American administration to establish its bases, but the reason was Behind the lack of attention of opponents to the idea of a military presence to the magnitude of what the United States is building in the countries of the world. It was also the reason why taxpayers were silent about their money going to build military bases they did not believe in.

But after the demise of the Soviet Union, the American administration became exposed; and questions were 
raised inside the US about these rules and their feasibility, as keeping these rules costs taxpayers approximately \$156 billion annually. To calm questions, the United States began to engage in the name of al-Qaeda, to combat terrorism, and recently the term "confronting ISIS" joined the justifications for the existence of these rules. However, the expansion of the bases towards the Arab Gulf increased doubts internally and externally about the fact that those rules were in order to confront the Soviet Union, or To deter terrorism only. Looking back a little, before al-Qaeda and ISIS, we find that in 1980 the American President Jimmy Carter established the Carter Doctrine, as he stressed that the United States will work to secure oil and natural gas in the Middle East region by any possible means, including military power. The first Gulf War came in 1991 to witness a qualitative shift in the American military presence in the region, as the United States worked to land hundreds of thousands of soldiers in Saudi Arabia and neighboring countries, but after the war ended many of these soldiers did not return to their home countries, according to what was mentioned in the book David Fein's Nation The rules, how American rules harm the United States ( 19)

Therefore, the Arab Gulf region will remain the most important military hub for the United States, especially in light of the American campaign against terrorism in the name of the "war on terror" announced after the events of September 11, 2001, based on the American desire to achieve goals that are: cutting financial support for "terrorist" organizations and obtaining On information in various ways, such as interrogation, eavesdropping, surveillance and inspection, improving the performance of external intelligence services and internal security, and establishing strong diplomatic relations with the governments of countries that are fronts of the war against terrorism

And that the United States of America through these military bases deployed in the Arab Gulf states is willing to maintain the security and stability of Israel from any foreign aggression attempt, support the proUS governments and defend them militarily against any threat by any country that opposes the American presence in the region, and secure transit routes Energy sources from the region to various countries of the world, which requires maintaining freedom of navigation in international waters, including the Gulf waters, and thus ensuring that the Strait of Hormuz remains open to the flow of oil, which is a strategic issue for the United States.

This Gulf embrace of the American military bases with such a huge amount, may be based on other justifications represented by the Iranian threat to the national security of the Gulf and that "the Gulf states realize that they cannot defend themselves alone; therefore, they need a greater force to shelter behind them if the need arises.

This is in addition to the fact that the human element in these countries is weak and unable to use these huge weapons that the Gulf states buy, such as what happened with Saudi Arabia in the Yemen war, where they suffered heavy losses due to the inability of their soldiers to control war machines, and the lack of their military expertise (20)

\section{CONCLUSION}

The beginning of the entry of American bases into the Middle East was in the third Gulf War, launched by the United States of America and its allies (United Kingdom, Poland, Australia, Spain, and Denmark) against Iraq, under the pretext that the latter possessed weapons of mass destruction, and began on March 20 until May 2003.

These bases formed an "area of influence" for America in the region, and were used to impose security and carry out specific operations against "terrorism", especially after the events of September 11, 2001, and the resulting occupation of both Afghan and Iraqi lands in 2001 and 2003, respectively.

The United States of America maintains close political and economic military ties with the Gulf states

,It is noteworthy that the Gulf crisis began after Saudi Arabia, the Emirates and Bahrain announced (Monday, 5 June 2017), to cut diplomatic ties with Qatar and close their common borders with them by land, sea and air, in an attempt to impose a complete blockade on 
Qatar, which they say is financing terrorist groups and organizations, which is What Qatar denied altogether.

However, this Gulf crisis will not significantly affect the joint military exercises and exercises between the United States of America and the Arab Gulf states

One of the strategic and strategic characteristics of the Arab Gulf region in the Middle East is its "transnational strategic importance", which is due to multiple factors, most notably its huge oil reserves, its control of major international shipping lines, the effects of the ArabIsraeli conflict and the chronic focus of the Iranian-Gulf conflict in the Arab Gulf. On the interests of the international parties

The GCC states face fundamental challenges and threats in a security-disturbed region, as was the case with Iraq's invasion of Kuwait in 1990 and Iran's continued occupation of the UAE islands, but the essence of the imbalance lies in the reasons for the inability of the GCC states to address any threats to their own security. And due to the linkage of this imbalance with the economic and political structure in the countries of the region, this complicates the problems associated with those structures

\section{REFERENCES}

1 Chantal de JongeOudraat (Editor).(18-20 April 1993). Conference of Research Institutions in the Middle East, Proceedings of the Cairo Conference(New York and Geneva) (p-2) United Nations Institute for Disarmament Research (Document UNIDIR/94/16).

2 Fred Wehling (Editor). (23, June 1996), Workshop on Arms Control and Security in the Middle East III, IGCC Policy Paper.(P. 6).

3: 1. Talaat Ahmad Muslim, The Foreign Military Presence in the Arab World, Beirut: Center for Arab Unity Studies, First Edition, 1994, pp. 83-92, and pp. 119-125.

4 The Message of Peace, issued by the World Peace Council in cooperation with the Egyptian Committee for Peace and Disarmament, Supplement No. 11, September 1990, p. 9.
5 Ali Al. Osmanoglu, A Turkish Perspective on Arms Control, in: Muhammad ZuhairDiab (translator and editor), Arms Control and Security in the Middle East: The Search for Common Ground, Cairo: Al-Ahram Center for Political and Strategic Studies, 1995, p. 81.

6 Hassan Mashhadi, Arms Control and Regional Security in the Middle East: An Iranian Perspective, in: Muhammad ZuhairDiab (Translator and Editor), Arms Control and Security in the Middle East: The Search for Common Ground, Ibid., P. 98

7 Abd al-Hay Zloum (Crusades) looked back in the 1980s. The United States began to exert pressure on Gulf states to obtain military support bases and facilities and the creation of the Ministry of Defense was what was known as the Central Command, CENTCOM, a new military command authority entrusted with the responsibility of the Gulf and the surrounding region of East Africa to Afghanistan. In 1987, when the Iran-Iraq war was at its height, the US Navy announced the formation of the joint Middle East force, which was tasked with protecting the oil tankers in the Gulf waters, thereby increasing the US naval presence in the Gulf, More than 40 pieces of aircraft carriers and warships and destroyers

8 Adam Hanieh, Capitalism and Class in the Gulf Arab States (New York: Palgrave Macmillan, 2011). pp. 3536

9 KennethKatzman. Oman: Reform, Security, and U.S. Policy. New York: Congressional Research Service. (August 30, 2001

US arms deals in the works with uneasy Gulf allies Fox News December 9, 201510

11- www.Global security.org

12- The Official Website of U.S. Department of defense 1

13 David R. Francis, "US bases in Iraq: a costly legacy" in Christian Science Monitor, April 3, 2006

-14 The strategy of building the American empire, a study by the retired Brigadier General Ahmed Allow, published on the official website of the Lebanese Army. 
(IJRSSH) 2020, Vol. No. 10, Issue No. II, Apr-Jun

http://www.lebarmy.gov.lb

15 The American Threat to America in the Gulf https://www.csis.org

16 Tenet, G. At the center of the storm: My years at the CIA. New York: Harper Collins, 2007.

17 The Heritage Foundation. 2016 Index of US Military Strength. Washington, DC, 2015. Accessed

January 15 , 2017.http://index.heritage.org/military/2016/assessment s/operating-environ

18 US Central Command. Shaping US Central Command for the 21stCentury: Strategic Plan II

.MacDill Air Force Base, FL: Office of the Commander-in-Chief, 1997.

\section{e-ISSN: 2249-4642, p-ISSN: 2454-4671}

US Congress. "Iraq Liberation Act of 1998" October 31, 1998. https://www.congress.gov

bill/105th-congress/house-bill/4655

19 US Department of Defense. Quadrennial Defense Review 2014. Washington, DC: US Department

of Defense, 2014.

http://archive.defense.gov/pubs/2014_Quadrennial_Def ense_Review.pdf

20 Walt, S. M. "In the national interest: A new grand strategy for U.S. foreign policy.” Boston Review

March 2005). Accessed January 15, 2017. http://bostonreview.net/archives/BR30.1/walt.php 